\title{
O poezji, styropianie i bardzo starych mitach
}

\author{
Agnieszka Dębska
}




\section{O poezji, styropianie i bardzo starych mitach}

Niewątpliwie okolicznościowa poezja polityczna powstaje, rozwija się i ma najlepiej wówczas, gdy są po temu warunki - w czasach niespokojnych, kiedy krajem wstrząsaja potężne konflikty, a wzburzone emocje prowokują do chwycenia za pióro. $\mathbb{W}$ jakim jednak wymiarze w państwie demokratycznego, w miarę spokojnego rozwoju może istnieć i mieć rację bytu doraźna poezja polityczna? Czy tylko w formie satyry kabaretowej lub spontanicznej twórczości wiecowej w rodzaju przeróbek Roty śpiewanych przez protestujących rolników? Czy też możliwa jest poezja tego typu, ujęta w kształt bardziej ambitny i wydawana w postaci autorskich tomików?

Próbę tego rodzaju przynosi książka Rzeczpospolita styropienna ${ }^{1}$.

Jej twórcą jest Stanisław Nawrocki, poeta związany z Płockiem, autor kilku tomów poetyckich publikowanych głównie w latach osiemdziesiątych pod pseudonimem Marka Bartnickiego. Jednakże Rzeczpospolita styropienna odbiega od dotychczasowej twórczości autora, jest to bowiem tom w całości poświęcony tematyce publicystycznej.

W większym jednak stopniu niż konkretnymi wydarzeniami i postaciami, także tu obecnymi, poeta zajmuje się ogólną charakterystyką sytuacji i stanu Polski po przełomie 1989 roku. Ocena tej sytuacji wypada bardzo negatywnie. Polska staje się krajem biedy, krajem

\section{(...) o jednym kierunku ruchu -} wybiegu na slumsy

\section{(zanim wyrok)}

Bardziej niż sama bieda dokucza wszakże to, że żyjemy w kraju rządzonym przez oszustwo i kult pieniądza, w kraju, w którym nastąpiła dewaluacja wszelkich wartości. Wolność będąca wynikiem umów okragłego stołu ma „kupieckie instynkty” (,vivat” magdalenka). Analizie stanu, w którym wszystko jest na sprzedaż, poświęcona została znaczna część omawianego tomu. Dlatego też wiele znajdziemy tutaj określeń zaczerpniętych ze współczesnego języka handlowego - mamy tu i „posezonową obniżkę cen” (Rzeczpospolita styropienna), „sprzedaż na raty” (pragmatycznym) i „hossę” (rota moja). Wielka wyprzedaż objęła zarówno wartości narodowe:

a kiedy już

wyprzedadzą najbardziej dumny kawałek nieba

z piastowską koroną na bakier

jak i religijne:

kiedy ukradkiem

kościelny hierarcha

zamiast na ołtarz złoży Chrystusa w lombardzie

(alternatywa)

${ }^{1}$ S. Nawrocki, Rzeczpospolita styropienna, Warszawa 1999, Wydawnictwo Książkowe IBIS, s. 78. 
Rozczarowanie do skutków „zwycięstwa”, które

Kraj czyści z wyjątków

z uczuć i ze świętości

(inwokacja)

potęgowane jest poczuciem zatarcia wartości, w imię których podejmowana była walka:

Kraju świątecznie wylewny któryś

w ferworze walki

pomylił imiona swych bohaterów

$\mathrm{z}$ imionami katów (...)

$$
\text { (oda polska) }
$$

Reakcją na doznawane krzywdy (wyraz „krzywda” pojawia się niezwykle często, to jeden z podstawowych elementów opisu współczesnej rzeczywistości) może być wybuch rewolucji, przy czym trudno zauważyć, by poeta witał taką ewentualność z obawą (alternatywa; implikacje; wtadcy spod styropianu).

Istotne dla charakterystyki pookragłostołowego ładu jest stwierdzenie jego obcości wolność, która nadeszła, jawi się jako „nietutejsza” („vivat” magdalenka). W ten sposób odżywa w książce Nawrockiego niezwykle typowy dla każdej poezji politycznej podział na "swoich” i „obcych”, podział wyrażany przy pomocy kluczowego przeciwstawienia „my” i „oni”. „My” to oczywiście ci, w imieniu których poeta przemawia, i z którymi się utożsamia:

ja

polak jakich miliony dziś na skraju Ojczyzny

(zanim wyrok)

Nie trzeba dodawać, że „my” to właśnie ci, którzy padają ofiarami wspomnianych „krzywd”.

Uwaga poety skupia się jednak przede wszystkim na „nie-swoich” (styropienni). To w nich wymierzona jest większość pomieszczonych w tomie wierszy, to przeciw nim — jak stwierdza poeta w otwierającej Rzeczpospolite styropiennq autoprezentacji -

\section{(...) miotam strofy jak szrapnele}

(zanim wyrok)

wpisując się tą niezwykle konwencjonalną deklaracją w tradycję poezji walczącej.

"Oni” to wszelkiego rodzaju przedstawiciele władzy: „elity” (linia demarkacyjna); "politycy” (kanalarze); „rządzący” (inwentaryzacja polska), „włodarze” (styropienni); „władcy” (wtadcy spod styropianu) etc. Przy czym chodzi raczej o rządzących w ogóle niż o konkretne postacie jedynie wiersz pod dość zaskakującym tytułem: politycy na nicy (językowych udziwnień znajdziemy w tym tomie więcej) jest satyrą z określonym adresem osobowym. „Władcy” mają dwie wspólne cechy: po pierwsze - wywodzą się spod znaku styropianu. Tytułowy „styropian" to przejrzysty, choć nieco deprecjonujący, symbol odwołujący się do strajkowej przeszłości postsolidarnościowej formacji. Po drugie są „obcy”, ponieważ wyznają obcy, zaczer- 
pnięty z Zachodu, system wartości. Rządzą zatem „z obcej poręki” (Rzeczpospolita stłropienna), „Z woli brukseli” (styropienni) — „brukseli” (lub „brukselki” — tak np. w wierszu „sukces”) koniecznie małą literą pisanej — arbitralne zasady stosowania małych i dużych liter oddają w pełni sympatie $\mathrm{i}$ antypatie autora. Zarzut "niewolnictwa” (wierszem $w$ nato), "wasalstwa” (zwiedzionym; oda polska) polskich polityków wobec Zachodu pojawia się w wielu wierszach. Szczególnie ostro atakowana jest idea przystąpienia do Unii Europejskiej (europatom; wchodzacym do europy; kanalarze; inwokacja; integrystom). Przedmiotem ataku są także „szpalty piekieł" (europatom), czyli środki masowego przekazu służące obcym celom:

media $z$ dnia na dzień

dostosują swoje sympatie do sztampy

byleby tylko jak najprędzej

zobaczyć nas

w Obozie Narodów Zniewolonych

— pisze Nawrocki w wierszu medialność, w typowy dla siebie sposób rozwiązując skrót ONZ.

Zachód jest w tej poezji symbolem wszelkiego zła (wręcz Imperium Zła...). Rządzi nim kult pieniądza i pozorna demokracja (linia demarkacyjna; kontynentni). Niechęć do instytucji Zachodu skupia się zwłaszcza na NATO (wierszem $w$ nato), szczególnie po nalotach na Jugosławię (do balkańskich braci; modlitwa na pożegnanie tysiqclecia; menażeria zła). Poeta staje w obronie „bałkańskich braci”, czyniąc ich reprezentantami Słowiańszczyzny, przeciwko którym występuje zło w postaci obcego, „pruskiego” ducha:

pruskim tropem krocza śmiało

śmierć hołubiąc nad głowami

$$
\text { (integrystom) }
$$

W przeszłości Zachód zawinił także wobec Polski:

$\mathrm{z}$ ich to przecież woli

pół wieku niewoli

się kiedyś zdarzyło

$$
\text { (w stronę zachodu) }
$$

W wierszu tamta europa Zachód jest odpowiedzialny nawet za „dwa wieki niewoli”.

Jednak w koncepcji Nawrockiego również Wschód nie jest bez winy. „Wschodnie narody” obciąża głód, niedostatek i zbrodnie totalitaryzmu (linia demarkacyjna; kontynentni). Zresztą totalitaryzm jest zdaniem poety wspólnym dorobkiem krajów Wschodu i Zachodu (nie doświadczaj nas; ich europa).

Pomiędzy tym wszystkim tkwi Polska — ,jak marysia sierotka” (inwentaryzacja polska), kraj

(...) o kulach po wschodniej i zachodniej stronie marzeń

(po stronie klęski) 
Miejsce Polski jest szczególne, jest ona

(...) przedmurzem obydwu tych światów

(linia demarkacyjna)

i ma w związku $z$ tym bardzo ważną rolę do odegrania. Przede wszystkim powinna więc zaprzestać „wasalstwa”, wyrzec się obcych wartości i „być Sobą” (zanim wyrok; „sukces”). „Bycie Sobą” oznacza Polskę, która „wieczna, mądra i cała” (hymn), i która jest wartością niemal sakralną:

Ojczyzna to wielu z nas w lepkiej powadze demonstrujący swe przywiązanie do Sacrum jedynie przez to żeśmy polskojęzyczni

(Ojczyzna)

Dlatego Polska dziś zniewolona i opuszczona przez wielu:

tylu od niej odstąpiło

dla korzyści lub przed siłą

$$
\text { (hymn) }
$$

zasługuje jednak na to, by jej służyć i dochować wierności mimo wyrzeczeń, tak jak deklaruje poeta w swoim wyznaniu wiary:

mimo hossy na żłób

wierność moją po grób

ja Tobie niosę

$$
\text { (rota moja) }
$$

Zarazem ucisk, jakiemu Polska jest poddana, przekracza wszystkie dotychczasowe doświadczenia. "nigdy dotąd nie doznaliśmy” — stwierdza poeta w wierszu nie doświadczaj nas — wyliczając następnie litanię krzywd, które spotykają obecnie naród polski. Nie pozostaje więc nic innego, jak prosić Boga:

odsuń więc Panie

ten kielich (...)

$$
\text { (nie doświadczaj nas) }
$$

Aby mesjanistyczny sztafaż wyrysować do końca, ukazany zostaje przyszły triumf Polski: ponad brukselą pekinem i moskwą ze żmijowiskiem pod stopa

(czyli: Podnóżem jego są trzy stolice...)

nadejdzie

Ta Polska (...) 
z miłością jak z butlą tlenową wróci (...)

nikt jej nie będzie prowadzić

$$
\text { (epilog) }
$$

(nikt? nawet aniot pacholę?)

W ten sposób objawione zostaje przyszłe zadanie Polski, która „będzie Sobą”.

Przy poruszaniu tego typu tematyki nie może oczywiście zabraknąć pytania o stosunek Boga do dziejącego się zła. Bóg jest proszony, jak już wyżej powiedziano, o pomoc dla Polski, ale w związku z ogromem krzywd pojawia się też zasadnicza wątpliwość:

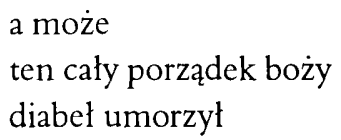

Jeśli zatem Bóg nie zemści się na państwach Zachodu za naloty na Belgrad, poeta jest gotów - znów wzorem Konrada - zakrzyknąć, iż jest On „u mocarnych na służbie” (modlitwa na pożegnanie tysiq̨clecia).

Okazuje się jednak, że naród wybrany zawsze może liczyć na Bożą opiekę:
lecz Bóg nie chce dla patosu łasce obcych nas powierzyć i z rzeźniczych eurostosów wyprowadzi swych żołnierzy

To fragment wiersza dedykowanego integrystom. Tekst ten, zarówno ze względu na obecność owych bożych ,żołnierzy”, jak i apokaliptyczną atmosferę:

mrok się jeży, pierzcha zorza

czas zaskomlał przestraszony

od gór szczytnych aż po morza

kroczą jurne eurogony

przypomina inny utwór o romantycznej proweniencji i identycznej wymowie:

Więc choć się spęka świat i zadrży słońce;

Chociaż się chmury i morza nasrożą;

Choćby na smokach wojska latające

Nas nie zatrwożą 2 .

W ten sposób dopełniony został krąg wyobrażeń, wśród których porusza się omawiana poezja. Mamy tu więc zarówno naród wybrany pod szczególną boską opieką, jak i mesjańską

2 J. Slowacki, Ksiq̨dz Marek, opr. M. Piwińska, Wroclaw 1991 (BN I 29), s. 5. 
misję miłości do wypełnienia, a więc motywy od bardzo dawna w polskiej poezji politycznej zadomowione. To, co zaskakuje, to ich niebywała żywotność i zdolność mutacji. Pojawiaja się one tutaj wszakże w kontekstach zupełnie współczesnych, które, na pierwszy rzut oka, nie powinny do tego typu rozpoznań prowadzić. Czyżby więc poezja polityczna musiała pozostać wciąż poezją tego samego mitu?

Owo przemieszanie dawnego i nowego znajduje wyraz także w języku, jakim Rzeczpospolita styropienna jest pisana. Mamy tu więc zarówno elementy stylu publicystycznego („poselskie ławy”; "grabież majątku narodowego”), jak i patetyczne archaizowanie („drzewiej”, „Sarmata”, „lechicki”), a wszystko to, dla oddania politycznej żarliwości, przyprawione ekspresywnym sosem kolokwializmów („menele”; „hycle”; „olać”).

A więc - mieszanka pod każdym względem zaskakująca. Czy jednak jest to zjawisko istotne? Niewątpliwie - warte zainteresowania, jako próba współczesnej, w demokratycznym państwie powstającej, poezji politycznej. Wiele idei zawartych w Rzeczpospolitej styropiennej może budzić kontrowersje, niektóre (np. sprawa „obcości”) wydawać się niebezpieczne. W całości jest to jednak raczej kontynuacja pewnych wątków i wyobrażeń wcześniej w literaturze obecnych $^{3}$ niż zapowiedź nowych tematów, raczej boczny tor niż początek nowej drogi.

Agnieszka Dębska

${ }^{3}$ Pisząc o ich wtórności, nie sposób nie zauważyć podobieństwa do ideologii Konfederacji Nowego Romantyzmu, z którą Nawrockiego w przeszłości łączono. 